\title{
Patent Buyouts: A Mechanism for Encouraging Innovation
}

\section{Citation}

Kremer, Michael R. 1998. Patent buyouts: A mechanism for encouraging innovation. Quarterly Journal of Economics 113(4): 1137-1167.

\section{Published Version}

http://dx.doi.org/10.1162/003355398555865

\section{Permanent link}

http://nrs.harvard.edu/urn-3:HUL.InstRepos:3693705

\section{Terms of Use}

This article was downloaded from Harvard University's DASH repository, and is made available under the terms and conditions applicable to Other Posted Material, as set forth at http:// nrs.harvard.edu/urn-3:HUL.InstRepos:dash.current.terms-of-use\#LAA

\section{Share Your Story}

The Harvard community has made this article openly available.

Please share how this access benefits you. Submit a story.

\section{Accessibility}




\title{
PATENT BUYOUTS: A MECHANISM FOR ENCOURAGING INNOVATION*
}

\author{
Michael Kremer
}

In 1839 the French government purchased the Daguerreotype patent and placed it in the public domain. Such patent buyouts could potentially eliminate the monopoly price distortions and incentives for rent-stealing duplicative research created by patents, while increasing incentives for original research. Governments could offer to purchase patents at their estimated private value, as determined in an auction, times a markup equal to the typical ratio of inventions' social and private value. Most patents purchased would be placed in the public domain, but to induce bidders to reveal their valuations, a few would be sold to the highest bidder.

Economic growth ultimately depends on the production of new ideas, but competitive markets do not provide appropriate incentives for the production of ideas. If consumers pay only the marginal cost of transmitting ideas, revenues will be insufficient to cover the cost of producing ideas. Historically, societies have used a wide variety of mechanisms to encourage production of ideas. Some, such as patents and copyrights, provide inventors with monopolies over goods produced using their ideas. Others, such as the National Science F oundation and the synthetic fuels program, directly subsi dize research. The United States uses both types of mechanisms: for example, government and industry each spent about $\$ 13$ billion on health research in 1992 [National Science Board 1993].

Creating monopolies in ideas and directly subsidizing research both lead to serious problems. Patents and copyrights create insufficient incentives for original research, since inventors cannot fully capture consumer surplus or spillovers of their ideas to other researchers. Patents and copyrights also create static distortions from monopoly pricing and encourage socially wasteful expenditures on reverse engineering to invent around patents.

Under symmetric information and full commitment, the first-best solution to underprovision of ideas is subsidizing research, rather than creating a new set of monopoly price distor-

* I thank Susan Athey, Edward Drozd, Glenn Ellison, Sara Ellison, Edward Glaeser, Zvi Griliches, Rebecca Henderson, Bengt Holmstrom, Eric Maskin, J ohn Matsusaka, Atif Mian, Robert Porter, Paul Romer, Andrei Sarychev, Steven Shavell, Kenneth Sokoloff, and two anonymous referees and the editor for comments and discussions, and Elizabeth Beasley and Sarah J atko for research assistance.

@ 1998 by the President and Fellows of Harvard College and the Massachusetts Institute of Technology.

TheQuarterlyJ ournal of Economics, November 1998 
tions through the patent system [Spence 1984]. However, before research is conducted, the government may not know the costs and expected benefits of research, and may not even be able to conceive of some inventions. Allowing government officials wide discretion to set payments to inventors ex post may lead to rent-seeking and to expropriation of investors after their research costs are sunk.

In 1839 the government of F rance combined elements of the patent system and of direct government support of research by purchasing the patent for Daguerreotype photography and placing the technique in the public domain. After the patent was bought out, Daguerreotype photography was rapidly adopted worldwide and was subject to myriad technical improvements. Such patent buyouts have the potential to eliminate monopoly price distortions and incentives for wasteful reverse engineering, while encouraging original research.

A major challenge for any system of patent buyouts is determining the price. This paper examines a mechanism through which the private value of patents would be determined using an auction. The government would offer to buy out patents at this private value times a fixed markup that would roughly cover the difference between the social and private values of inventions. Inventors could decide whether to sell or retain their patents. Patents purchased by the government would typically be placed in the public domain. However, in order to provide auction participants with an incentive to truthfully reveal their valuations, the government would randomly select a few patents that would be sold to the highest bidder. Encouraging innovation through such a mechanism would require more discretion by government officials than the current patent system, but substantially less discretion than that exercised by, say, the National Institutes of Health.

As discussed by Dutton [1984] and Shavell and Ypserle [1998], the relative merits of rewards and patents were widely debated in the nineteenth century. Macife[1869], a member of the British Parliament in the nineteenth century, proposed replacing the patent system with a reward system. In this century Polanvyi [1943] suggested replacing patents with rewards based on ex post estimates of the value of inventions. Guell and Fischbaum [1995] suggest that the government use its power of eminent domain to purchase pharmaceutical patents. They proposethat judges determine the buyout price. One problem with allowing broad administrative discretion over the patent buyout price is that this may 
lead to purchases at confiscatory prices, and thus reduce incentives for innovation. Allowing broad discretion may also lead to wasteful expenditures on rent-seeking, and if some groups in society are better able to organize politically than others, this rent-seeking may distort the pattern of research [Cohen and Noll 1991]. This paper describes how a market mechanism could be used to determine the value of patents. As a safeguard against confiscation of inventions, patent holders could choose whether to sell their patents. Patent buyouts would thus supplement, rather than replace, the existing patent system. I nventors would receive a markup over the private value of the patents, so as to bring incentives for invention closer to the social value. This paper also differs from Guell and Fischbaum in addressing the problem of creating proper incentives for the development of complementary and substituting inventions. Shavell and Ypserle [1998] argue that a system in which inventors could choose between rewards and patents would be superior to a pure patent system. One problem with a fixed reward is that people could claim rewards for trivial inventions. General Motors could stick a useless piece of metal onto a Chevrolet, and as long as the automobile sold due to other attractive features, GM could argue it deserved the reward. More generally, this paper is related to a broader literature on the potential of various mechanisms to encourage innovation [J ohnston and Zeckhauser 1991; Romer 1993; Taylor 1995; Baker 1996; Lichtman 1997;' Scotchmer 1997].

The paper is organized as follows. Section I argues that the distortions associated with both patents and direct government support of research are severe enough that other methods of encouraging research should be explored. Section II discusses the historical experience of patent buyouts. Section III explains how an auction could be used to estimate the value of patents, and thus determine the buyout price. Section IV discusses equilibrium behavior in the auction when inventors have private information about the value of patents, or are the low-cost producers of the patented good. Section $V$ discusses incentives for marketing and development of inventions under patent buyouts. Section VI

1. Lichtman [1997] has suggested that the government subsidize lowvaluation consumers so as to avoid distortions from monopoly pricing through a form of price discrimination. Note that targeting subsidies to low-valuation consumers requires that the government have lots of information, and that if the patent owner had this information, it could price discriminate. Moreover, Lichtman's proposal does not bring private research incentives in line with social incentives. 
outlines rules that would be necessary to deal with substituting and complementary patents. Perhaps the chief problem with patent buyouts is that they are potentially vul nerable to collusion, since inventors could bribe auction participants to submit high bids. Section VII discusses several ways the government could control collusion. Section VIII argues that patent buyouts should focus on the pharmaceutical industry. It suggests that a limited trial of patent buyouts could be conducted first, perhaps, by a private foundation. If the buyouts seem successful, the program could betried on a larger scale.

\section{Mechanisms for Encouraging InNovation}

This section argues that the distortions associated with encouraging research through patents and through direct government support are sufficiently severe that it is worth investigating additional mechanisms for encouraging innovation.

\section{I.A. Patents}

Encouraging research through patents creates static distortions, underinvestment in research, and distortion of research toward duplicating existing inventions.

Static distortions arise as people who value the good above the marginal cost of production do not consume it at the monopoly price. To take a particularly dramatic example, monopoly pricing of AZT makes it impossible for HIV-positive pregnant women in developing countries to prevent transmission to their children, leading to hundreds of thousands, if not millions, of cases of pediatric AIDS. To see that financing research with monopoly profits not only is not first best, but is generically less efficient than financing research through tax revenue, consider the problem of a social planner choosing a tax to finance research. The principles of Ramsey taxation should clearly guide the planner's decision, and it is highly unlikely that the optimal tax will be a several thousand percent tax on the patented good. Yet financing research by giving monopoly rights to inventors is equivalent to such a tax.

Patents create far too little incentive for original research, since potential inventors will not take consumer surplus into account when deciding whether to undertake research. To take another dramatic example, Michael Milken would presumably pay hundreds of millions of dollars for an effective drug to fight 
prostate cancer, but pharmaceutical companies do not take this into account in setting their research budgets, since they will not be able to extract Milken's consumer surplus. Under the crude assumption that willingness to pay for drugs is proportional to income, calculations using U.S. household income distribution data from the 1995 CPS suggest that the social value of new pharmaceuticals is 2.7 times the profits that would be extracted by a monopolist who could not price discriminate. The deadweight loss due to monopoly pricing would be one-quarter of the sum of profits and consumer surplus. ${ }^{2}$

Another reason patents create insufficient research incentives is that they do not reward researchers for the externalities they create for other researchers. Theoretically, these externalities could either be positive, through knowledge spillovers, or negative, through patent races. However, the available empirical evidence suggests that on balance, researchers usually create positive externalities for other researchers. J affe [1986] finds that, controlling for technological opportunities, firms whose neighbors invest more in research and development have more patents per dollar of $R \& D$ and a higher return to $R \& D$. Cockburn and Henderson [1993, 1994] find similar results for pharmaceutical firms, even after controlling for measures of technical opportunity. They conclude that, "far from 'mining out' opportunities, competitors' research appears to be a complementary activity to own R\&D."

An extensive empirical literature suggests that social returns to innovation far exceed the private returns. Nadiri [1993] summarizes this literature and finds that social rates of return to $R \& D$ average close to 50 percent. Mansfield et al. [1977] examine seventeen innovations in detail, and find an average social rate of return of 56 percent, compared with a 25 percent private rate of return. In his exhaustive study of the CT scanner industry, Trajtenberg [1990] finds that the social return to $R \& D$ was 270 percent, orders of magnitude above the private return.

The available evidence thus suggests that the social rate of return on research and development is at least twice the private rate of return, given the quantities consumed under monopolistic pricing. The social rate of return would be even greater if inventions were priced at marginal cost, so that the deadweight

2. Price discrimination may reduce this deadweight loss, but it is unlikely to allow pharmaceutical companies to capture much of the consumer surplus from the tail of high-income, high-valuation customers. 
loss due to monopoly pricing was avoided. If the deadweight loss due to monopoly pricing is one-quarter of profits plus consumer surplus (as would be the case given the U. S. income distribution if willingness to pay were proportional to income), the social return to research under marginal cost pricing would be $2 \times 5 / 4=2.5$ times the private rate of return on research under the current patent system.

Patents also distort the direction of research by creating too much incentive to develop substitutes for patented goods and too little to create complements. By devel oping substitute inventions, firms can steal rents from existing patent holders. The limited available evidence suggests that this problem may be severe. Mansfield, Schwartz, and Wagner [1981] find that 60 percent of a sample of patented innovations were imitated within four years, and that the average imitation cost was two-thirds the original cost of invention. Potential developers of complementary inventions, on the other hand, will have too little incentive to develop these inventions if they must sink costs into developing the complementary inventions before concluding licensing agreements with owners of original patents [Green and Scotchmer 1982]. Sometimes, agreements between owners of complementary patents are not reached (perhaps because of asymmetric information), and inventions remain unused. For example, the development of the high pressure steam engine was blocked by Watt's patent covering all steam engines; Watt's steam engine was blocked by a previous patent until he found a way to invent around it; and Edison's improved version of the telegraph was blocked by Bell's prior patent for many years [Mokyr 1990].

Since a substantial fraction of research funds are spent on wasteful duplication of existing products, the social rate of return to original research is substantially higher than the overall rate of return to research. Based on Mansfield's [1981] estimates, a reasonable guess is that one-quarter of research funds are spent on socially wasteful duplication and that three-quarters are spent on original research. In this case, the social return to original inventions would be $4 / 3$ as large as the average social return to research, which, as discussed above, may be 2.5 times the private return. Thus, the social return to original research may be 3.33 times the private return, implying that patents create far too little incentive for original research. In the analysis below, I will generally make the conservative assumption that the social value of patents is on average only twice the private value. 


\section{I.B. Direct Government Support of Research}

Since ideas are nonrival, standard public goods arguments suggest that research should be publicly financed. However, governments' efforts to finance research are plagued by asymmetric information between researchers and governments. When the government pays for research input, rather than output, it is difficult to prevent researchers from shirking, either by applying little effort or by focusing on areas of purely scientific interest. The work of Nadiri [1993], Nadiri and Manuneas [1994], and Bernstein and Nadiri [1988, 1991] suggests that the rate of return on privately financed $R \& D$ is much higher than that on publicly financed $R \& D$. Lichtenberg [1992] makes the extreme estimate that the within-country social return to private research and development is seven times as large as the return to investment in equipment and structures, but that the social return to government-funded research and development is insignificantly different from zero. ${ }^{3}$

Paying for research output through prizes creates much stronger incentives for researchers than paying for research inputs through grants. Prizes were more frequently used in the past than they are today, and stimulated inventions ranging from food canning to the chronometer [Wright 1983]. Wright [1983] and Scotchmer [1997] argue, however, that the potential of prizes is limited because governments lack information on the benefits (or even possibility) of many inventions before they have been invented. This would be less of a problem if governments could specify prizes ex post, but in this case, the authority awarding prizes might be tempted to expropriate inventors by offering inadequate prizes. This may be a problem even for prizes ostensibly specified ex ante, if the rules governing prize awards are not clear. Sobel [1995] relates the difficulties the inventor of the chronometer encountered in claiming the British government's $£ 20,000$ prize for a method of determining longitude at sea. ${ }^{4}$

Another problem with direct government support of research is that small groups who are strongly affected by particular government decisions may lobby to influence these decisions, distorting research expenditures [Cohen and Noll 1991; Romer 1993]. F or example, some argue that lobbying by defense contrac-

3. However, see Toole [1997] for an alternative view.

4. However, others are more sympathetic to the prize administrators [Paul David, personal communication]. 
tors and AIDS activists has distorted the pattern of military and medical research expenditures.

\section{Historical Experience of Patent Buyouts}

During the early nineteenth century, when both patents and prizes were used to to encourage invention, there were at least two cases in which governments combined the patent and prize systems by buying out patents. Such patent buyouts are attractive since they offer the opportunity to eliminate monopoly pricing distortions and incentives for duplicate research, while raising rewards for original research. It is worth exploring how they functioned in practice.

In 1837 Louis J acques Mande Daguerre invented photography by developing the Daguerreotype process. He exhibited images created using the process, and offered to sell detailed instructions to a single buyer for 200,000 francs or to 100 to 400 subscribers at 1,000 francs each. Daguerre was not able to find a buyer, but obtained the backing of $\mathrm{F}$ rancois Arago, a politician and member of the Academie des Sciences, who argued that it was “... indispensable that the government should compensate $M$. Daguerre direct, and that France should then nobly give to the whole world this discovery which could contribute so much to the progress of art and science. ${ }^{\prime \prime} \mathrm{I} \mathrm{n}$ J uly 1839 the $F$ rench government purchased the patent in exchange for pensions of 6000 francs per year to Daguerre, 4000 francs to his partner, and half that amount to their widows upon their death. The French government then put the rights to Daguerre's patent in the public domain (except in England, where the French government allowed Daguerre's original patent to remain in force). The invention was rapidly adopted and subjected to technological improvements. Within months, Daguerre's instruction manual was translated into a dozen Ianguages. Many complementary inventions improved the chemistry and lenses used in Daguerre's process.

In England, William Fox Tal bot had developed the calotype process independently, and when he heard of Daguerre's process, he patented his own system in 1841 [Nelson 1996]. The Daguerre process became the standard, while the English process was abandoned, perhaps in part because Talbot charged high fees for use of his process. However, twenty years later a new process was

5. Cited in Nelson [1996]. 
developed, which also involved making prints from negatives, as had Tal bot's process. The subsequent devel opment of photography followed this colloidotype process.

Like Daguerre, Eli Whitney was unable to make much money from his patent [Green 1956]. The cotton gin could be easily replicated by local carpenters and blacksmiths, and Southern juries were creative in finding technicalities on which to rule against Whitney in the many patent infringement suits that he filed. In 1802, facing bankruptcy, Whitney sold the South Carolina rights to the cotton gin to the state government for $\$ 50,000$, a tiny fraction of the millions of dollars in surplus generated by the invention. In 1803, on rather flimsy pretexts, South Carolina suspended payment on the unpaid balance of its debt to Whitney, sued to recover the money Whitney had already been paid, and even had him arrested. However, the legislature of 1804 reversed the annulment of 1803. Later, Whitney sold the rights to the cotton gin in North Carolina and Tennessee to the state governments in exchange for an agreement that the states would tax cotton gins and pay the proceeds to Whitney.

Rewards have also been used in more modern times. The United States Patent Compensation Board compensates developers of innovations of military value relating to atomic energy. The former Soviet Union rewarded process innovators with a percentage of the cost savings created by their invention [Sinnot 1988]. It is worth trying to draw a few lessons from the experience of the cotton gin and Daguerreotype patent buyouts. In both cases the government purchased important patents. The political economy problem with patent buyouts does not seem to be that unscrupulous rent-seekers bribe government officials to purchase patents for useless inventions, but rather, as Whitney's experience suggests, that once a good is invented, governments may be tempted to expropriate the inventor.

Both the Daguerreotype and the cotton gin were adopted rapidly after the patents were bought out, and were subject to further technological development afterward. Although we do not have evidence on the counterfactual, it seems plausible that the free availability of the inventions led to wider adoption, and that this increased incentives and opportunity for the development of technological improvements.

The Daguerreotype example indicates that buying patents may increase inventors' incentive to patent discoveries, rather than relying on trade secrecy. The release of information on 
Daguerre's techniques led to positive externalities for other researchers, hel ping createscientific advances in chemical reactivity and solar spectrum analysis [Barger and White 1991].

A final, cautionary, lesson is that buying out patents and putting them in the public domain will reduce adoption of substitute innovations which remain under patent. It seems possible that the Daguerreotype process was too widely adopted because it was free, whereas the Talbot process was costly. It is unclear which process was superior, but it is possible that selectively putting patents in the public domain could lead to the adoption of inferior technology.

\section{A Mechanism for Buying out Patents}

A key problem in designing any system of patent buyouts is developing a mechanism to determine the price at which patents would be bought out. I deally, the patent buyout price would be the social value of the invention, since this would provide incentives to invest in research only if the expected social benefit exceeded the cost. 6

Scotchmer [1997] argues that patents are an optimal way of rewarding research if the value of inventions is private information of the researcher. While the value of potential inventions may be private information of the researcher before research is conducted, other firms in the industry are likely to have at least some information on the private value of the invention after inventions are patented. This paper explores one way to use this information to determine a patent buyout price.

A standard way of eliciting information on the value of indivisible goods, such as patents, is through auctions. Figure I shows how an auction could be used to determine the price at which the government would offer to buy out patents. Under the mechanism, the market value of patents would be determined through a sealed-bid second-price auction, ${ }^{7}$ and the government would then offer to buy patents at this private value times some constant markup which would reflect the typical ratio of social to private value. Most of the patents that the government bought would be placed in the public domain. However, in order to give

6. Many readers may think that this rule needs to be modified to take account of the deadweight loss associated with taxation; for an argument that such adjustment should not be made, see Kaplow [1996].

7. Sealing the bids may make collusion more difficult. 


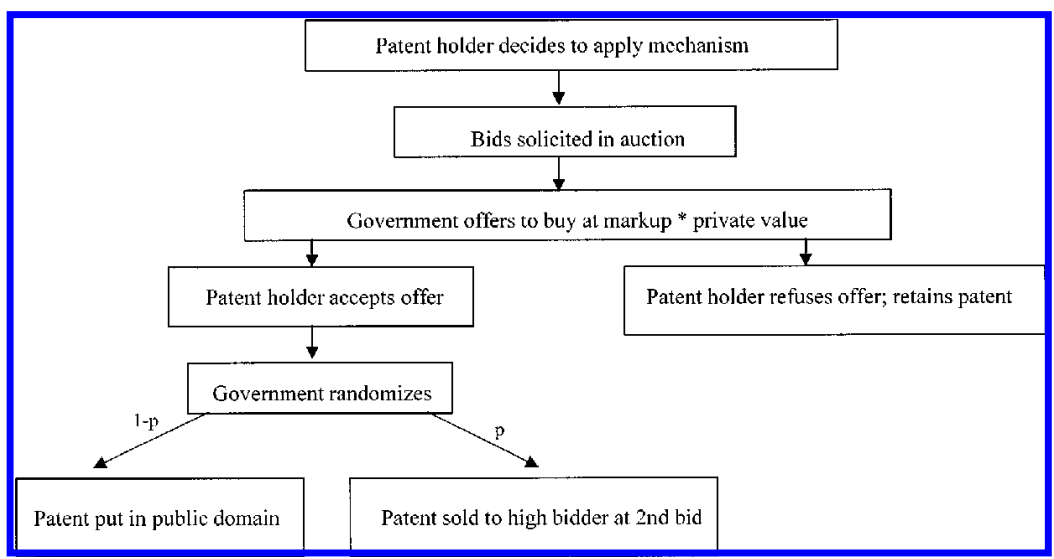

FIGURE I

Auction Mechanism for Patent Buyouts

auction participants an incentive to reveal their true valuations, a small proportion of patents, chosen randomly, would be sold to the high bidder. Patent holders would have the right to accept or reject the government's offer. Although the government might require a waiting period following either patenting or FDA approval of new drugs before it would buy out patents, patent holders would be free to postpone patent buyouts. I nventors who wished to sell their patents to the government would be responsible for paying for the administrative costs of the auction.

Based on the empirical estimates of the social return to innovation discussed above, it seems likely that the government should offer to buy patents at a markup of at least twice their estimated private value. This will not match the social value of inventions, but it is likely to be a better approximation than the private value of patents, which is what inventors receive in the absence of patent buyouts.

Under a sealed-bid, second-price auction, auction participants will bid their expectation of the patent's value, given their information, conditional on their making the winning bid. It will be efficient for the government to estimate the private value using information from the entire distribution of bids, rather than only the highest bid, since there is no reason to throw away the information provided by the other bids. If the government knew the prior distribution of valuations, it would be able to aggregate 
the information of all bidders to estimate the private value of the patent. In practice, the government does not know the bidders' prior distribution of valuations. Therefore, it might be best for the government to use a simple rule, such as offering the original patent holder some multiple of the third highest bid. ${ }^{8}$

The next sections consider the operation of the patent buyout mechanism in several different environments: with inventor cost or informational advantages; with complementary or substituting inventions; and with the threat of collusion. As discussed in Section VIII, this analysis suggests that pharmaceuticals may be particularly well suited to patent buyouts. However, before considering these more complicated cases, it is worth first reviewing the advantages of patent buyouts in a perfectly competitive, collusionfree environment.

1. The markup would raise private incentives for original research closer to the social benefit created by the invention.

2. Deadweight losses due to monopoly pricing would be eliminated if patents were put in the public domain.

3. Since monopoly profits would be eliminated, researchers would not have excessive incentives to invent substitutes for existing drugs to steal profits.

\section{InVEntor Cost or Informational AdVAntages}

If inventors have private information about the value of the patent or are the low-cost producers of the patented good, they will be more likely to reject the government's offer to buy their patents. This section argues, however, that unless these cost or informational advantages are extreme, the markup will still lead most inventors to sell their patents. In those cases in which inventors do refuse to sell their patents, the system of patent buyouts would be equivalent to the current patent system.

It is useful to consider two polar extremes of auction environments. Subsection IV.A examines the case of a common value auction in which the original inventor is better informed about the patent's value than other bidders are. Subsection IV.B examines

8. Because this type of rule is robust to outliers, it makes the system less prone to disruption by a few crazy bidders, or, as discussed in Section V, by collusion. For example, if it were thought that the social value of inventions were typically $\mathrm{M}$ times the private value, the private value was $Y$ times the value of the highest bid, and the highest bid was typically $Z$ times the third highest bid, then the government would offer MYZ times the third highest bid. 
the case of a private value auction in which the inventor has the highest value for the patent and there is some dispersion of valuations among bidders.

\section{IV.A. I nventor I nformational Advantage}

If the inventor has private information about the value of the patent, the winner's curse will lead bidders to make low bids [Milgrom and Webber 1982; Hendricks and Porter 1988; Hendricks, Porter, and Wilson 1994]. However, the winner's curse may be greatly mitigated by the markup.

Consider an example in which the patent has a common value, the inventor knows this value, and conditional on the information reveal ed by the FDA drug approval process, potential bidders know only that the value is distributed uniformly in $(L, U)$. The bidders will know that if a bid of $B$ leads to the good being sold by the inventor, then the true private value of the patent is uniformly distributed in $(L, \min (U, M B))$, where $M$ is the markup. In equilibrium, auction participants will bid the expected value of the patent, conditional on their bid being accepted, or $(L+\min (U, M B)) / 2$. This implies that

$$
B=\min \left(\frac{L+U}{2}, \max \left[0, \frac{L}{2-M}\right]\right) .
$$

The markup mitigates an adverse selection problem that could otherwise shut down the market for patents. If $M=1$, so there were no government markup, auction participants would bid L, and patent owners would never sell their patents. F or a markup of 2 , auction participants will bid $(L+U) / 2$, the government will offer to buy out patents for $L+U$, and patents will al ways be sold.

This extreme result depends on the assumption that the value of the patent is uniformly distributed. If the distribution of the value of patents conditional on the information available to bidders is skewed, then although adverse selection will be reduced by the markup, it may not be eliminated. The unconditional distribution of the realized value of FDA-approved drugs is extremely skewed [Grabowski and Vernon 1990], but there is likely to be much less variance and skewness in the distribution of the expected value conditional on the information available to bidders, including the number of people suffering from the disease, the availability of competing drugs, and the efficacy and side effects of the drug as revealed during the FDA approval process. Moreover, a skewed distribution of realized values of 
patents does not necessarily imply a skewed distribution of beliefs about the expected value of the patent. After all, the skewness of realized values of lottery tickets is extremely high, but there would be only minor problems of asymmetric information in selling lottery tickets. Note also that inventors will have an incentive to reveal as much information as possible about the invention, so as to reduce adverse selection in bidding. As a referee has pointed out, asymmetric information about the value of inventions makes sales of pharmaceutical patents by small biotech firms to larger pharmaceutical firms complicated, and sometimes blocks them entirely. Nonetheless, since such transactions frequently take place currently without any government markup, it seems likely that many patents would be sold in the presence of a 100 percent markup.

\section{IV.B. I nventors Who Are L ow-Cost Producers}

Inventors are often the low-cost producers of their inventions because they own complementary assets, such as marketing networks or unpatented intangible information on production techniques. However, inventors will still typically sell their patents, because the government will offer a markup and because the inventor will still be able to produce the good if the patent is placed in the public domain.

To focus on the effect of differences in cost among potential producers, suppose that the inventor can produce at a cost $c_{0}$, that the ith lowest cost producer can produce at cost $c_{i}$, and that demand for the good is given by $\mathrm{Q}=\mathrm{P}^{\alpha}$, where $\alpha<-1$. For a patent holder with cost $c_{i}$, the optimal price is $c_{i} \alpha /(\alpha+1)$, which yields profits of

$$
\pi_{i}=c_{i}^{1+\alpha}\left(\frac{\alpha}{\alpha+1}\right)^{\alpha}\left(\frac{-1}{\alpha+1}\right) .
$$

Under a second-price seal ed-bid auction, each auction participant will bid its valuation, $\pi_{i}$. Suppose that the government offers to buy out the patent at $M Z \pi_{j}$, where $\pi_{j}$ denotes the value of the jth highest bid, $Z$ is some multiplier, such as the historical ratio of the jth highest bid to the highest bid, and $M>1$ is the markup. Inventors will sell their patents to the government if $\pi_{0}<M Z \pi_{j}+$ $(1-p) \pi_{\text {СомP }}$, where $\pi_{0}$ is the value to the inventor of a monopoly on the good, $p$ is the probability that patents purchased by the government will be transferred to the high bidder, and $\pi_{\text {СОмР is }}$ the value to the original inventor of producing the good in 
competition with other firms. If the patent is placed in the public domain, and if $c^{\prime} / c<\alpha /(\alpha+1)$, so the inventor's cost advantage is not too large relative to the monopoly markup, then under Bertrand competition, the inventor will limit price and obtain profits $\pi_{\text {COMP }}=\mathrm{C}_{1}^{\alpha}+\left(\mathrm{c}_{1}-\mathrm{c}_{0}\right)$.

Given the drastic markups in pharmaceuticals, and the ease of manufacturing most pharmaceuticals, this condition for limit pricing is likely to be fulfilled. However, if $c_{1} / c_{0}>\alpha /(\alpha+1)$, so the inventor's cost advantage is drastic, and if the patent is placed in the public domain, the inventor will sell the good at the monopoly price, and obtain profits $\pi_{0}$. In this case, patent buyouts will not ameliorate monopoly price distortions. This suggests that patent buyouts are likely to be most desirable in industries in which prices would be considerably lower in the absence of patents, such as the pharmaceutical industry. Patent buyouts are also more desirable in industries where cost differences aresmall, since they would occasionally entail transferring the patent to higher-cost producers. (As discussed in Section VII, patent buyers would not be allowed to resell the patent to the original owner, because this could facilitate collusion.)

To see why inventors will typically sell their patents, note that if $c_{j} / c_{0}<(M Z)^{-1 /(1+\alpha)}$, so the cost-advantage is not too great relative to the markup, then $M z \pi_{j}>\pi_{0}$. On the other hand, if $c_{1} / c_{0}>\alpha /(\alpha+1)$, inventors will sell the patent for sufficiently small $p$, because their monopoly price will not be constrained by competition, and hence $\pi_{0}$ will equal $\pi_{\text {сомp }}$.

If potential bidders differ in their valuations, but must spend some resources to learn their valuation, the costs of processing information are likely to reduce entry into the auction, and hence reduce the average winning bid in equilibrium. Presumably, bidding costs will besmaller relative to the value of the patent for more valuable patents, so bidding costs will be less likely to deter bidding on pharmaceuticals which have already undergone FDA approval, and thus arelikely to be valuable.

Despite the markup, there will be cases in which asymmetric infrastructure, cost advantages, or bidding costs lead bids to be so low that the inventor will refuse to sell the patent. In such cases, existing patent rules will remain in force, and (abstracting from administrative costs) nothing will have been gained or lost by the procedure. Since inventors who wish to sell their patents would be responsible for covering the adminstrative costs of the auction, they would not use the mechanism in those cases in which they 
anticipated bids would be less than half the value of the invention. Hence, the administrative costs of the auction would not be incurred in those cases in which it is clear that the mechanism would not succeed.

\section{Incentives for Product Development}

Incentives for marketing and development are likely to be enhanced by patent buyouts. Suppose that the private value of a patent is $\pi(E)$, where $E$ denotes expenditures on development and marketing. In the absence of patent buyouts, patent owners will invest in development until $\partial \pi / \partial \mathrm{E}=1$. Patent owners who expect to sell their patent at a markup of $M$ will invest until $\partial \pi / \partial E=1 / M$. Inventors would be free to delay patent sales to first undertake devel opment and marketing if they wished.

Some opportunities for further development may appear only after patents have been sold. F or example, technological advances in related fields may open up new opportunities for development after the patent has been bought out. Patent buyouts will strengthen incentives for this further development if it can be patented or appropriated in some other way. This is because the market for a complementary invention will be larger if the original invention is sold at marginal cost. Moreover, the developer of the complementary invention will not have to split its value with the original inventor or take the risk that unresolved patent disputes with the original inventor will block new complementary products.

Although patent buyouts increase inventors' incentive to conduct development prior to the buyout, and increase others' incentives to conduct development after the buyout, they reduce inventors' incentives to conduct unpatentable development after patent buyouts. For example, pharmaceutical firms have much less incentive to test for new uses for generic drugs than for patented drugs. In practice, there may be other ways of appropriating investment in marketing and development. For example, some aspirin manufacturers have sufficient market power that even without patent protection they advertise aspirin's effectiveness in preventing heart attacks. The substantial technological improvements to the Daguerreotype process and the cotton gin after the patents were bought out provide at least some suggestion that patent buyouts do not generally greatly discourage further technological development. In any case, pharmaceuticals 
typically need little new development after they have been approved by theFDA. ${ }^{9}$

\section{Substitute and Complementary Patents}

Anticipation that future substitute patents will be bought out will reduce current research incentives in two ways. As subsection VI.A shows, patent buyouts act as a subsidy to research, increasing the chance that future substitutes will be developed quickly. To attain the socially optimal level of research, the markup must therefore be greater than the ratio of the social value of inventions to their private value given the current level of research. Subsection VI.B shows that anticipated buyouts of substitute patents also deter current research by causing future patents to be placed in the public domain, and thus to be more formi dable competitors. In order to preserve incentives for current research, patent buyouts would incorporate a rule that if a patent remains in private hands and a substitute patent is put up for auction, the holder of the original patent could have it jointly randomized with the new patent. Either both patents would be placed in the public domain, or both patents would be transferred to their respective high bidders. Complementary patents would also be jointly randomized, as discussed in subsection VI.C.

\section{A. Patent Buyouts as Research Subsidies}

The expectation that future patent buyouts will encourage research on substitutes will partially offset the tendency for the markup to spur research. The optimal markup will therefore be greater than the current ratio of the social value of inventions to their private value. To see this, consider models of creative destruction such as Aghion and Howitt [1992] or Grossman and Helpman [1991], in which each invention is eventually subject to competition from future inventions. Under these models, research at time $t, x_{t}$, can be written as $x_{t}=\phi\left(M_{t}, x_{t+1}\right)$, where $M_{t}$ is the subsidy to research at time $t, \phi_{1}>0$, and $\phi_{2}<0$. Suppose that there is a constant markup $M$. Denote the research effort that would be chosen by a social planner as $x^{5}$. I assume that $x^{5}$ is

9. If complete patent buyouts prevented development, the mechanism could be modified to allow some market power in newly invented goods. For example, the government could offer to buy out the last ten years of a patent after it had been in private hands for seven years. Alternatively, rather than placing patents in the public domain, the government could sell a limited number of licenses to produce the good, converting what would have been a monopoly into an oligopoly. 
greater than $x^{p}$, the level of research undertaken in the absence of patent buyouts. ${ }^{10}$ The optimal markup $M^{s}$ solves $x^{s}=\phi\left(M^{s}, X^{s}\right)$. The optimal markup will be the typical ratio of the social value of inventions to their private value, given that the socially optimal amount of research will be conducted in the future. $\mathrm{M}^{\mathrm{s}}$ is greater than the markup needed to induce research $x^{5}$ given the expectation that future patents will not be bought out, $M^{p}$, since $M^{p}$ solves $X^{S}=\phi\left(M^{p}, X^{p}\right)$. To see the intuition, note that the expected lifetime of patents, and hence their private value, will be lower if more research is expected in the future. Hence the ratio of social to private value under patent buyouts will be greater than the ratio of social to private value without patent buyouts. This implies that the optimal markup is even larger than the figure of 2 to 3.33 suggested by Section II.

\section{VI.B. J oint Randomization for SubstitutePatents}

Patent buyouts at time $t+1$ may reduce incentives for research at time t not only by encouraging research at time $t+1$, but also by causing inventions at time $t+1$ to be placed in the public domain and sold at marginal cost, and thus to be more formidable competitors for inventions developed at time t. ${ }^{11}$ As explained below, incentives for current research can be preserved by holding a joint randomization to determine whether substitute patents would each be put into the public domain, or each be transferred to their respective high bidders.

To see why anticipated patent buyouts with separaterandomization could weaken current research incentives, note that bids for a new patent would be reduced by the likelihood that future substitutes will be put in the public domain. For example, people would bid less for the patent on Prozac if they expected that the patent on Zoloft would be put in the public domain. (This point is shown formally in a working paper version of this paper [K remer 1998].)

J oint randomization could preserve incentives for current research. It would work as follows: if the patent on one invention was in private hands, and a substitute was invented and put up for auction, the holder of the original patent could ask for it to be

10. Although equilibrium research effort may be either greater or less than optimal in models of creative destruction, the empirical evidence suggests that the current patent system produces too little research and development [j] ones and Williams 1995].

11. This effect does not arise in the Aghion and Howitt model because they assume that all inventions are drastic. 
reauctioned at the same time as the substitute patent. Prospective buyers would bid on each patent separately, but the government would conduct a single randomization to determine whether the original and substitute patents would be put in the public domain or whether each would be sold to the high bidder in its auction. ${ }^{12}$

Note that joint randomization does not require a bureaucracy to judge whether goods are substitutes. Any patent holder could claim that his or her patent was a substitutefor a new patent, and request that it be jointly randomized with the new patent. Even if the new patent was not in fact a substitute for the old patent, jointly randomizing the old patent together with an unrelated new patent would create no harm and would have the advantage of possibly transferring another patent to the public domain.

Under joint randomization, each patent will be valued based on the contingency in which both it and a possible future substitutestay in private hands, as shown in K remer [1997]. J oint randomization or reversion to the existing patent system would occur only if the original patent remained in private hands. Presumably, these cases would be rare, because most patents would be sold to the government and placed in the public domain.

The analysis above assumes that demand for the original invention is affected only by the contemporaneous price of the substitute, not the expected future price. This assumption seems appropriate for nondurable goods-that is, goods which are destroyed when they are consumed, such as most pharmaceuticals. However, as discussed in Kremer [1997], demand for durable, nonrentable goods will be reduced by anticipated buyouts of future substitute patents, even under joint randomization. Patent buyouts along the lines discussed in this paper may therefore be less appropriate for such patents.

\section{VI.C. J oint Randomization for Complementary Patents}

Whereas anticipation that substitute patents will be put in the public domain reduces the price at which patents are bought out, anticipation that complementary patents will be bought out increases the buyout price. Under separate patent buyouts, inventors are paid the marginal value of their inventions, condi-

12. If the original inventor had not previously sold the original patent to the government, then the government would pay a markup on the original patent, but if the original had been through a previous patent buyout, the government would not pay a second markup. 
tional on the other complementary patents being bought out. The sum of these marginal values may be greater than the total value of a set of complementary inventions.

To see this in a simple case, consider an example in which two complementary inventions each have private value $0.1 \pi$ individually but have value $\pi$ together, and suppose that the social value of the patents alone or together is twice their private value. If one patent is put in the public domain, then the reward for invention of the other patent will be $0.9 \pi$ times the markup. This implies that under separate patent buyouts the developers of each patent can expect to receive approximately $0.9 \pi$ times the markup, since bidders for the first patent will anticipate that the second patent is likely to be put in the public domain and by the time the second patent has been invented, the first patent will probably be in the public domain. This will create excessive incentives for creation of the pair of inventions, since the social value of the pair is only $2 \pi$. (It would also create an incentive for inventors to divide up inventions into multiple complementary patents.)

To reduce the possibility that the government pays more than the social value of complementary patents, and to avoid creating incentives for inventors to split up inventions into multiple patents, the government should not separately purchase complementary patents. Patent owners who do not wish to sell jointly would not have to sell their patents, but they would not be eligible for future, separate patent buyouts. I nventors who sell one patent to the government would not be eligible to sell future complementary patents to the government until after a waiting period elapsed.

If a set of drugs were complementary, the government would offer to buy out the set together, and if the offer were refused, the government would then offer to buy out only a (randomly selected) single member of the set. A markup of two suffices to ensure that a single owner of an arbitrary number of complementary patents will al ways prefer to sell all the patents to the government, rather than to sell one patent and retain the others. ${ }^{13}$

If complementary patents were held by different owners, the government would solicit bids both on those patents belonging to

13. To see this, note that the patent owner will receive $M \pi$ in exchange for a set of patents which are worth $\pi$ together and zero al one. The owner would receive a maximum of $M \pi / 2$ in exchange for all but one of the patents. The remaining patent will be worth $\pi$ with probability $1-p$ and a maximum of $\pi / 2$ with probability $\mathrm{p}$. The owner will therefore prefer to sell all the patents as long as $M \pi>M \pi / 2+(1-p) \pi+p \pi / 2$, or equivalently, if $2-p<M$. 
each owner and on the entire set of complementary patents. If the owners could not agree to a joint sale, the government would offer to buy the patents controlled by one owner picked randomly, with probability proportional to the estimated value of its patents.

The government could determine whether the patents were very strong complements by looking at the pattern of bids. If a set of patents are complements, the sum of the bids for subsets will be less than the bids for the entire set (assuming that the bidders anticipate they will not perfectly cooperate in pricing the goods after buying out the patents). If the government mistakenly classified patents as complements and refused to buy out each patent separately, patent owners would not be harmed if they agreed to sell jointly, and even if they could not agree to sell jointly, they would still be better off than under the current patent system, as long as at least one member of the set of complementary patents was put in the public domain.

One of the advantages of buying out patents for pharmaceuticals is that complementary patents are considerably less common in pharmaceuticals than in other industries. Whereas in many fields, inventions are typically protected by several patents, pharmaceuticals are much more often protected by a single patent. ${ }^{14}$ This is in part because a new drug is often a particular molecule, and in part because the FDA approval process is so expensive that it does not make sense to break a drug into two separate drugs, each of which have to be approved separately. Of course, some drugs are complements. For example, a chemotherapy drug may create side effects, and another drug may alleviate those side effects.

\section{Vil. Preventing Collusion}

The auction mechanism is potentially vulnerable to collusion, since patent holders would have an incentive to bribe auction participants to bid high. The bidder would only have to pay the government with probability p. However, with 100 percent probability, the patent holder would receive an inflated payment. It is impossible to eliminate collusion, but, as subsection VII.A explains, a variety of mechanisms could be used to minimize

14. Sometimes a new drug will be protected both by a product patent and by process patents on techniques manufacturing. The government could refuse to buy process patents separately, and only agree to buy product patents when sold together with any associated process patents. 
collusion. Subsection VII.B discusses how the prices paid by the government for patents could belimited by ceiling prices based on actual sales of the patented pharmaceutical.

\section{VII .A. Mechanisms for Preventing Collusion}

The government could make collusion more difficult using standard procedures such as requiring bids to be sealed, punishing companies and individuals found guilty of collusion, and rewarding whistle-blowers. This would make collusion more difficult and more dangerous. Several additional methods specific to patent buyouts could also be used.

1. The government would base the price it offers the inventor on the third highest bid. The original patent holder would therefore have to bribe three companies instead of one to ensure a substantial increase in the buyout price. This should significantly increase both the difficulty of collusion and the chance of detection.

2. The agency purchasing patents could have authority to call the bluff of suspected overbidders by reducing the markup and selling to the high bidder without randomization in a set percentage of cases. For example, suppose that based on the other bids, and any knowledge of the industry, the government's best estimate of the patent's value was $\pi$. If a bidder offered $\pi+\mathrm{x}$ and the government suspected collusion, ${ }^{15}$ the government could offer to buy out the patent at $\pi+\$ 1$, and then require the suspected colluding bidder to purchase the patent at its bid of $\pi+\mathrm{x}$. The government would make a profit of $x-1$ from the attempted collusion.

3. The government could develop lists of suspect bidders by checking whether winning bidders made money, since systematic overbidders would incur big losses.

4. To prevent inventors from forming front companies and having them submit high bids, bidders would have to provide information on any ties they had with the inventor. Bidders who lied about financial ties with the inventor would be subject to prosecution.

5. Bidders could be required to pay a licensing fee or deposit allowing them to participate in a number of auctions. This

15. Collusion could be indicated by an abnormally high variance of bids; entry of companies that had not participated in the past; or high bids by suspected colluders relative to those from a known group of "honest" bidders. 
would make it unprofitable for patent holders to set up dummy companies simply to bid on their own patents.

Excluding bidders will be costly if there are only a few potential bidders, but there will often be many potential bidders, because it is straightforward to manufacture most drugs, as evidenced by the fact that there are often many different producers of generic drugs. (F or example, fourteen firms produce oral al buterol sulfate.) Any system of patent buyouts that relies on auctioning patents should focus on drugs that are easy to produce, rather than those which require complicated manufacturing facilities.

6. To prevent inventors from developing a reputation for buying back their patents at inflated prices, inventors would be prohibited from buying back the patent from the winning bidder, or making other payments to bidders. Preventing these side payments might be one of the most difficult aspects of preventing collusion.

At least in the early years of any program of patent buyouts, the government agency administering the program would presumably have a budget for patent buyouts, and would not be able to afford all the patents that were available for purchase. One option would be to allow the agency to choose which patents to purchase, so that if the price for a particular patent was too high, it could decline to purchasethe patent and cancel the randomization. This would tend to reduce collusion because raising the patent buyout price would reduce the chance that the patent would be bought out.

\section{VII.B. Ceiling Prices}

Because patent sales are voluntary, the private value of the patent acts as a floor on the patent buyout price. If the mechanisms for limiting collusion discussed in the previous subsection were thought inadequate, there are several ways that governments could establish ceiling prices, and thus reduce the risk of paying vastly inflated sums for patents.

1. A waiting period of several years could be required before patents were bought by the government, and ceiling prices could be set as a multiple of annual revenues prior to the patent buyout. A waiting period would also make it easier for bidders to assess the value of patents, and would further guarantee that inventors would have incentives 
for marketing and development. Of course, setting ceiling prices as a multiple of prebuyout revenue would lead firms to artificially boost sales, for example by offering hospitals discounts on other drugs in exchange for purchasing the patented drug, or even by paying outright kickbacks. Tied sales would have to be prohibited. A second ceiling could be established based on the prebuyout pricetimes postbuyout consumption.

2. The amount paid for patents could be capped by total sales of the drug following the patent buyout, times an administrative estimate of the social value of the drug per dose or per patient. I nternational estimates of the cost in disabilityadjusted life years of various diseases are already available. These could be combined with information on drug effectiveness from FDA trials to estimate a ceiling price per dose. Setting these ceilings requires administrative discretion, but the associated rent-seeking may be limited by the fact that setting a ceiling only requires a fairly transparent decision about the social value of the drug per dose. Public interest groups could monitor attempts to set outrageous prices per dose more easily than they can monitor whether the NIH is subsidizing pure science in the guise of developing an AIDS vaccine or whether national laboratories and breeder reactors are being created for pork barrel or scientific reasons. The historical record suggests that the political economy problem in setting patent buyout prices is more that governments have an incentive to expropriate inventors ex post than that inventors wrangle huge sums for unimportant products.

3. It also might be worth considering a mechanism like that in Figurell, with a ceiling price based on the actual profits obtained from the new drug. Inventors who wished to participate would have their patents randomized. The patent would be randomized to the high bidder with some probability $p$, and placed in the public domain with probability $1-p$. Inventors would be paid only if the patent was randomized to the high bidder. In this case, they would receive $(M / p) \min (b i d, \pi)$, where $M$ is the markup, bid is the estimated value of the patent based on the bids, and $\pi$ is the realized revenue (or ideally profits) 


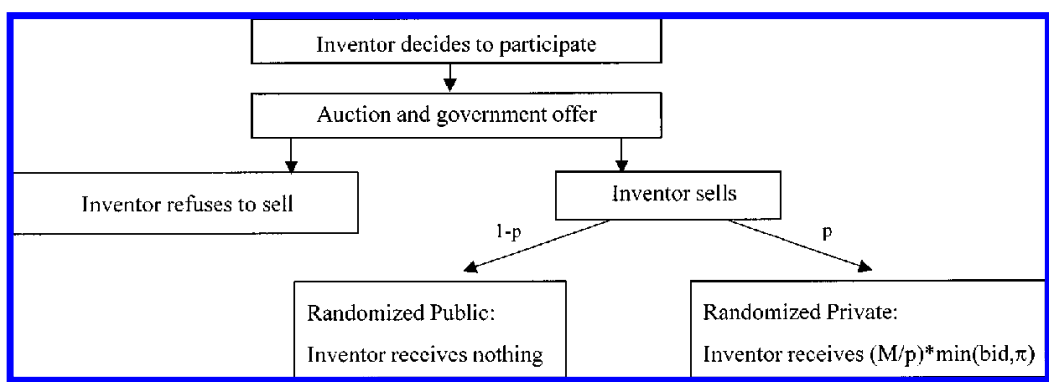

FIGURE II

Patent Buyouts with Ceiling Prices

from the drug. The expected payment received by the inventor is thus $\mathrm{M}$ min (bid, $\pi$ ). ${ }^{16}$

Inventors could try to manipulate the ceiling price by bribing thehigh bidder toboost sales artifically through tieins with other products. The government would have to monitor bidders carefully to minimize such tie-ins. While tie-ins will cost the government money, they will not necessarily reduce efficiency, since by increasing sales they may counteract the static distortions created by monopoly pricing. The majority of patents would be put in the public domain so the issue would not arise, and in any case, it is likely to be difficult for firms to greatly increase demand artificially for drugs covering serious sharply defined diseases, such as cystic fibrosis.

It is easy to dream up scenarios under which people could evade rules designed to discourage collusion, but it is also important to remember that many institutions which are theoretically vulnerable to collusion operate relatively well. F or example, peer-review is highly vulnerable to collusion, yet the National Science Foundation and the National Institutes of Health seem relatively effective. Moreover, limited collusion is not necessarily that harmful. Collusion itself is not a problem; deadweight losses

16. This mechanism does not require the inventor to bear nearly so much risk as it may seem at first glance. Inventors should be able to insure themselves at rates which are close to actuarially fair against the possibility that the patent will be randomized to the high bidder, since this probability is objective and known to all (unlike the value of patents, about which inventors may have private information). I nventors would sign contracts under which they would receive $\$ x$ in every state of the world, and pay $\$ x / \mathrm{p}$ if their patents were sold to the high bidder. Risk-averse inventors would like to buy enough insurance to receive ME[min $(\mathrm{bid}, \pi)$ ] in every state of the world, where the expectation is taken conditional on the inventors' information. 
due to collusion are a problem, and there is little reason to think that these deadweight losses would exceed the deadweight losses due to insufficient original research, monopoly-price distortions, and the diversion of effort to "me too" research in the absence of patent buyouts. Even if collusion raises patent prices above their social value, the social value of inventions may be approximated better by the collusive price than by the existing patent system, under which private incentives for developing new inventions are likely to be less than half the social value of the inventions. Finally, if implicit collusion were expected to significantly raise patent prices, then the markup over the private value could be reduced accordingly. For example, if the optimal markup was three (as seems plausible), and if collusion were thought to raise prices by up to 50 percent, then the government could simply offer a markup of two.

The auction mechanism described in this paper may be appropriate for many pharmaceuticals, but it would not be appropriate in industries where markets are too thin for auctions, or patents are not an effective means of protecting inventions. In such industries the government could simply offer to buy out patents for an amount equal to postbuyout sales times an administratively determined estimate of the average consumer surplus per unit of the good consumed.

\section{Vili. Conclusion: Trial Patent Buyouts}

Previous sections have examined the potential of patent buyouts to supplement our current system of promoting innovations through patents and direct government support of research. The government could offer to buy out patents at their private value, as revealed by an auction, times a markup designed to cover the difference between the private and social values of inventions. This mechanism involves more government discretion than the current patent system, but substantially less discretion than government funding of research through the NSF or NIH. Patent buyouts could potentially increase incentives for original invention closer to their social value; reduce incentives for wasteful "me too" research; and eliminate monopoly pricing distortions. On the other hand, patent buyouts could also cause a number of problems, including collusion to raise buyout prices.

When new institutions are proposed, there is a natural tendency to focus on their potential risks and shortcomings. 
However, it is also important to recognize that existing mechanisms of encouraging innovation have serious flaws. In an 1851 editorial (cited by Dutton [1984]) urging that patents be abolished, TheE conomist wrote that the granting of patents "inflames cupidity, excites fraud, stimulates men to run after schemes ... begets disputes and quarrels betwixt inventors, provokes endless lawsuits [and] makes men ruin themselves for the sake of getting the privilege of a patent, . . ."All this is true, and yet it seems clear that the world is much better off with patents than without them. The same may betrue for patent buyouts.

Since it is difficult to gauge the effects of patent buyouts based on theory alone, and since large-scale patent buyouts would be risky, it might be useful to first try patent buyouts on a limited basis. Such a trial could help determine whether inventors would sell their patents, and whether bids would be substantially greater than realized profits or revenues, as would be the case if collusion were severe. This would help policy makers judge whether patent buyouts should beabandoned, redesigned, or used more widely.

Pharmaceuticals are a natural area to try patent buyouts, since markets would be relatively competitive in the absence of patents; patent protection is effective; monopoly markups are large; drugs are nondurable; "me too" inventions are widespread; and considerable information is generated during FDA trials, so potential bidders could make informed bids. ${ }^{17} \mathrm{M}$ oreover, because many pharmaceutical patents are valuable, the administrative costs of the system are likely to be small relative to the benefits of patent buyouts. Once F DA approval has been granted, little new development is typically required.

Finally, buying out pharmaceutical patents is likely to have benign distributional consequences, whereas buying out, say, patents for improved yachts will not. Financing pharmaceutical research through patents places the financing burden on disease victims. If disease incidence is random, and not fully insurable, people will prefer ex ante to insure themselves by funding the research out of general tax revenue.

The system could initially be applied to treatments for a few specific diseases considered to be particularly important, or

17. Distortions in the market for health care may actually strengthen the case for buying out pharmaceutical patents. Although people may consume too much health care due to subsidies, subsidies for pharmaceuticals are generally smaller than for alternative, more expensive, treatments, such as surgery, so pharmaceutical subsidies maybe desirable on second-best grounds. 
particularly subject to problems resulting from the patent system. Orphan drug legislation provides a precedent for establishing special rules for drugs designed to treat particular diseases.

A private foundation could conduct an initial trial of patent buyouts. If the experience of the foundation patent buyout was positive, the government could consider appropriating, say, $\$ 100$ million from general revenue or from the NIH budget for patent buyouts.

One precedent for innovative philanthropic support of research is the million dollar prize established by the Rockefeller Foundation for invention of a diagnostic test for gonorrhea and chlamydia suitable for use in developing countries. The social value of such a diagnostic test is likely to far exceed the private value, since gonorrhea and chlamydia are believed to increase the likelihood of HIV transmission three-to-five fold [Rockefeller Foundation 1997]. Although gonorrhea and chlamydia are easily treated, millions of people go untreated because diagnostic tests suitable for use in developing countries are not available. The prospect of patents does not seem to have encouraged sufficient research on diagnostic tests, and in any case, monopoly pricing of such diagnostic tests might dramatically reduce the number of people tested and treated, spurring the spread of HIV.

A shortcoming of prizes, including the Rockefeller Foundation prize, is that they do not allow for trade-offs among various performance criteria. To be eligible for the Rockefeller Foundation prize, diagnostic tests must be 99 percent accurate, take less than twenty minutes, require no more power than can be delivered by a nine-volt battery, be storable for six months in tropical conditions, cost less than U.S. $\$ 0.25$ per device to manufacture, and be usable by health workers with only primary education after two hours of training [Rockefeller Foundation 1997]. I deally, the specifications would be much more flexible, since it is possible that it would be very hard to design a test that would exactly meet the Rockefeller Foundation's specifications, but easy to create a test that was slightly less accurate, but much cheaper, faster, and simpler to use.

Perhaps the Rockefeller Foundation should consider announcing that if the prize has not been claimed by the date the offer expires (March 1, 1999), it would consider using the funds to buy out a patent on a diagnostic test that does not completely fulfill the prize criteria. The foundation might want to buy only part of 
the patent rights, given the limited funds it is making available. For example, the foundation might buy out the last ten years of the patent. In such an auction, the auction participants would bid for the full rights to the patent, and with probability $1-p$ the foundation would offer to buy out the last ten years of the patent for its estimated full value, and with probability $p$ the foundation would buy out the patent fully, at twice its estimated full value, and then sell the patent rights to the highest bidder at the second highest bid.

This paper has examined the use of auctions to determine patent buyout prices, but the general approach to limiting government discretion through public auctions may be more widely applicable. Optimal mechanism design often requires decisions tailored either to individuals, or to small numbers of agents. However, government rules typically restrict the use of some types of information. For example, civil service rules limit discretion over pay and promotion decisions. Similarly, there are extensive rules restricting what types of evidence are admissible in trials, even though other information could shift priors. This paper has considered a system that allows governments to tailor decisions to individuals without allowing unlimited government discretion over small numbers of people. To induce people to reveal the information needed by the government, an auction is held in which bidders need only be awarded the item with a small probability. I am currently exploring whether a similar mechanism can be used to determine a price at which taxpayers would be all owed to purchase exemption from distortionary taxation.

MASSACHUSETTS InStitute OF TECHNOLOGY

\section{References}

Aghion, Philippe, and Peter Howitt, "A Model of Growth through Creative Destruction,"E conometrica, LX (March 1992) 323-351.

Baker, Dean, "The High Cost of Protectionism: The Case of Intellectual Property Claims," mimeo 1996.

Barger, M. Susan, and William B. White, TheDaguerreotype(Washington, DC, and London: Smithsonian Institution Press, 1991).

Bernstein, J., and M. I. Nadiri, "Interindustry R\&D, Rates of Return, and Production in High-Tech Industries," American Economic Review, LXXVIII (1988), 429-434.

Bernstein, J., and M. I. Nadiri, "Product Demand, Cost of Production, Spillovers, and the Social Rate of Return to R\&D," NBER Working Paper No. 3625,

$\mathrm{J}$ anuary 1991 .
Center for Drug Evaluation, Food and Drug Administration, Approved Drug Products with Therapeutic EquivalenceE valuations, Volume 16 (Washington, DC: U. S. Department of Health and Human Services, Public Health Service, 1996). 
Cockburn, Ian, and Rebecca Henderson, "Racing to Invest: The Dynamics of Competition in Ethical Drug Discovery," Massachusetts Institute of Technology, Sloan School of Management, September 1993.

Cockburn, I an, and Rebecca Henderson, "Racing or Spilling? The Determinants of Research Productivity in Ethical Drug Discovery," Massachusetts I nstitute of Technology, Sloan School of Management, 1994.

Cohen, Linda R., and Roger G. Noll, TheTechnology Pork Barrel (Washington, DC: Brookings I nstitution, 1991).

Dutton, $\mathrm{H}$. I., The Patent System and Inventive Activity During the Industrial Revolution 1750-1852 (Manchester: Manchester University Press, 1984).

Grabowski, Henry, and J ohn Vernon, "A New Look at the Returns and Risks to Pharmaceutical R\&D," Management Science, XXXVI 36, No. 7 (J uly 1990), 804-821.

Green, Constance MCL., Eli Whitney and the Birth of American Technology (Boston, MA: Little Brown and Company, 1956).

Green, J erry R., and Suzanne Scotchmer, "Antitrust Policy, the Breadth of Patent Protection and the Incentive to Devel op New Products," Harvard I nstitute for Economic Research Discussion Paper No. 1467, Cambridge, MA, 1982.

Grossman, Gene M., and Elhanan Hel pman, I nnovation and Growth in the Global Economy (Cambridge, MA: MIT Press, 1991).

Guell, Robert C., and Marvin Fischbaum, "Toward Allocative Efficiency in the Prescription Drug Industry," TheMilbank Quarterly, LXXIII (1995), 213-229.

Hendricks, Kenneth, and Robert H. Porter, "An E mpirical Study of an Auction with Asymmetric Information," American E conomic Review, LXXVIII (1988), 865883.

Hendricks, Kenneth, Robert H. Porter, and Charles A. Wilson, "Auctions for Oil and Gas Leases with an Informed Bidder and a Random Reservation Price," Econometrica, LXII (November 1994), 1415-1444.

J affe, Adam, "Technological Opportunity and Spillovers of R\&D: Evidence from Firms' Patents, Profits, and Market Value." American Economic Review, LXXVI (December 1986), 984-1001.

J ohnston, Mark, and Richard Zeckhauser, "The Australian Pharmaceutical Subsidy Gambit: Transmuting Deadweight Loss and Oligopoly Rents to Consumer Surplus," NBER Working Paper No. 3783, J uly 1991.

J ones, Charles I., and J ohn Williams, "Too Much of a Good Thing? The Economics of I nvestment in R\&D," Working Paper, August 1995.

Kaplow, L ouis, "The Optimal Supply of Public Goods and the Distortionary Cost of Taxation," National Tax J ournal, XLIX (December 1996), 513-533.

Kremer, Michael, "Patent Buyouts: A Mechanism for Encouraging Innovation," available from the author at the Massachusetts I nstitute of Technol ogy, 1998.

Lichtenberg, Frank R., "R\&D I nvestment and International Productivity Differences,"NBER Working Paper N o. 4161, 1992.

Lichtmann, Douglas G., "Pricing Prozac,"Yale Law School Working Paper, 1997.

Macfie, R. A., Recent Discussions on the Abolition of Patents for Inventions (London: L ongmans, Green, Reader, and Dyer, 1869).

Mansfield, Edwin, Mark Schwartz, and Samuel Wagner, "Imitation Costs and Patents: An Empirical Study," Economic | ournal, XCl (December 1981), 907-918.

Mansfield, Edwin, et al., The Production and Application of New Industrial Technol ogy (New York, NY: W. W. N orton \& Company, 1977).

Milgrom, Paul, and Robert Weber, "The Value of Information in a Sealed-Bid Auction,"J ournal of Mathematical E conomics, X (J une 1982), 105-114.

Mokyr, J oel, The Lever of Riches: Technological Creativity and E conomic Progress (New York, NY: Oxford University Press, 1990).

Nadiri, M. I shaq, "Innovations and Technological Spillovers," NBER Working Paper No. 4423, 1993

Nadiri, M. I shaq, and Theofanis P. Mamuneas, "The Effects of Public Infrastructure and $R \& D$ Capital on the Cost Structure and Performance of U.S. Manufacturing Industries," Review of Economics and Statistics, LXXVI (February 1994), 22-37.

National Science Board, Science and Engineering Indicators (Washington, DC: U. S. Government Printing Office, 1993). 
Nelson, Kenneth E., A Thumbnail Sketch of Daguerreotypes, Online, The Daguerrian Society, 1996, http://java.austinc.edu/dag/resources/history/

Polanvyi, Michael, "Patent Reform,"Review of E conomic Studies, XI (1943), 61-76. The Rockefeller Foundation, The STD Diagnostics Challenge: Rules and Regulations (New York, NY: The Rockefeller Foundation, February, 1997).

Romer, Paul, "I mplementing a National Technol ogy Strategy with Self-Organizing Industry I nvestment Boards," National Bureau of E conomic Research, reprint No. 1870, 1993.

Scotchmer, Suzanne, "On the Optimality of the Patent System," University of California, Berkel ey Working Paper No. 236, October 1997.

Shavell, Steven, and Tanguy van Ypserle, "Rewards versus Intellectual Property Rights," mimeo, Harvard Law School, 1998

Sinnot, J ohn P., World Patent Law and Practice, Volume 2M (New York: Matthew Bender, 1998).

Sobel, Dava, Longitude(New York, NY: Walker and Company, 1995).

Spence, Michael, "Cost Reduction, Competition and Industry Performance," Econometrica, LII (J anuary, 1984), 101-121.

Taylor, Curtis R., "Digging for Golden Carrots: An Analysis of Research Tournaments," American Economic Review, LXXXV (September 1995), 872-890.

Toole, Andrew, "The Impact of Federally Funded Basic Research on Industrial Innovation: Evidence from thePharmaceutical Industry," mimeo, Christensen Associates, Madison, WI, 1997.

Trajtenberg, Manuel, E conomic Analysis of Product Innovation: The Case of CT Scanners (Cambridge, MA: Harvard University Press, 1990).

Wright, Brian D., "The Economics of Invention Incentives: Patents, Prizes, and Research Contracts," American Economic Review, LXXIII (September 1983), 691-707. 


\section{This article has been cited by:}

1. E. Schroth, D. Szalay. 2009. Cash Breeds Success: The Role of Financing Constraints in Patent Races. Review of Finance . [CrossRef]

2. U. Pagano, M. A. Rossi. 2009. The crash of the knowledge economy. Cambridge Journal of Economics 33:4, 665-683. [CrossRef]

3. Tina C. Ambos, Kristiina Mäkelä, Julian Birkinshaw, Pablo D'Este. 2009. When Does University Research Get Commercialized? Creating Ambidexterity in Research Institutions. Journal of Management Studies 45:8, 1424-1447. [CrossRef]

4. Robert Bird, Daniel R. Cahoy. 2008. The Impact of Compulsory Licensing on Foreign Direct Investment: A Collective Bargaining Approach. American Business Law Journal 45:2, 283-330. [CrossRef]

5. KRISTINA M. LYBECKER, ROBERT A. FREEMAN. 2007. Funding pharmaceutical innovation through direct tax credits. Health Economics, Policy and Law 2:03, 267. [CrossRef]

6. Carl Nathan. 2007. Aligning pharmaceutical innovation with medical need. Nature Medicine 13:3, 304-308. [CrossRef]

7. Shubham Chaudhuri, Pinelopi K Goldberg, Panle Jia. 2007. Estimating the Effects of Global Patent Protection in Pharmaceuticals: A Case Study of Quinolones in India. American Economic Review 96:5, 1477-1514. [CrossRef]

8. Stan J. Liebowitz, Richard Watt. 2006. HOW TO BEST ENSURE REMUNERATION FOR CREATORS IN THE MARKET FOR MUSIC? COPYRIGHT AND ITS ALTERNATIVES. Journal of Economic Surveys 20:4, 513-545. [CrossRef]

9. ELIZABETH WEBSTER, PAUL H. JENSEN. 2006. Investment in Intangible Capital: An Enterprise Perspective*. Economic Record 82:256, 82-96. [CrossRef]

10. Scott Stern. 2004. Do Scientists Pay to Be Scientists?. Management Science 50:6, 835-853. [CrossRef]

11. Tim Hubbard, James Love. 2004. A New Trade Framework for Global Healthcare R\&D. PLoS Biology 2:2, e52. [CrossRef]

12. Michael Stolpe. 2003. Weltweiter Patentschutz für pharmazeutische Innovationen: Gibt es sozialverträgliche Alternativen?. Perspektiven der Wirtschaftspolitik 4:4, 437-448. [CrossRef]

13. Stephen Schmidt. 2002. Incentive Effects of Expanding Federal Mass Transit Formula Grants. Journal of Policy Analysis and Management 20:2, 239-261. [CrossRef]

14. Paul Romer. 2002. When Should We Use Intellectual Property Rights?. American Economic Review 92:2, 213-216. [CrossRef]

15. Michael Reich. 2001. Aids 15, S14-S17. [CrossRef]

16. Stephen M Maurer, Suzanne ScotchmerPROCURING KNOWLEDGE 1-31. [CrossRef]

17. Sumner La Croix, Ming LiuChapter 13 Patents and Access to Essential Medicines 423-464. [CrossRef] 